\title{
Cultural Transformation and Chinese Contemporary Female Literature Development
}

\author{
Ping Chen ${ }^{1}$, Yanfeng $\mathrm{Si}^{1}$ \\ ${ }^{1}$ XingTai University,Xingtai,054001,China
}

\begin{abstract}
Keywords: Contemporary Female Literature, Cultural Transformation, Female Literature Confusion, Changing Individuals of Female Literature Development
\end{abstract}

\begin{abstract}
Chinese feminine literature has really realized "de-sexualized writing", and formed independent writing way and writing style from the 1980s or the 1990s. With the constantly profound reform and opening-up policy in China and deep transformation of social culture, female ideology has been constantly set free. Chinese female writers finally got rid of traditional male chauvinism and created plenty of literary works with bright female consciousness and emotional characteristics. This paper through retrospecting the idea course of Chinese feminine literature development analyzes the current cultural transformation's positive and negative impacts on female literature and further understands the development and change tendency of Chinese contemporary female literature.
\end{abstract}

\section{Introduction}

Cultural development and prosperity is a significant standard of social culture progress and economic development. Prior to the 20th century, Chinese female literature merely existed as the auxiliary literature of male chauvinism. It is not hard to see after carefully studying the history of Chinese literature that female literature still takes a considerable proportion. Many works have been spread up to now and are highly appreciated and widely read. Literature is beautiful for its diversity. With the constant transformation of social culture, female literature's "de-sexualized writing" development marks the improvement of women's social status and forms magnificent scenery in the contemporary literary world.

\section{Idea course of Chinese female literature development}

Chinese female literature originated early and had a long history which can be traced back to the Western Han Dynasty in record. The poem Silver Threads among the Gold written by Zhuo Wenjun, “They're telling me your thoughts are double; that's why I've come to break it off; today is just like the last party; we will leave each other tomorrow like water in gutter way", takes the story of Sima Sheung-yu and Zhuo Wenjun as chief source to create and expresses the author's extremely independent female consciousness. In the Jin Dynasty and the Sui, the Tang and the Five Dynasties, there were lots of female literature representatives like Zi Ye, Li Zhi, Yu Xuanji, Xue Tao, etc. They are mostly knowledgeable and brilliant poem prostitutes. Because of their female identity, they felt depressed and frustrated and finally became prostitutes for livelihood. For example, Xue Tao wrote a poem named Reward for Enjoying Bamboo after the Rain, "If you come to enjoy the bamboo again in the end of this year, you can see its integrity of not fearing the wind and snow". Li Qingzhao [1] in Song Dynasty who was labeled as "the greatest female litterateur throughout history" by literature historians created Memorizing piping the yeasty barrel on Phoenix Terrace, A Spray of Plum Blossoms, To the Tune of Intoxicated under the Shadow of Flowers, etc. He integrated his unfortunate destiny with time variation description, expressing a sense of deep-rooted family and national enmity. Representative works in Ming and Qing Dynasty include Madame Song of Yang Shen's step-wife named Huang Yueying, Tao Huaizhen's Rain Flowers, Liu Qingyun's The Lgend of Place for Celestial Beings in Small Penglai, etc. All these above are the representative works of Chinese ancient female writers. Specific history has determined that the female writers have to grow up in the edification of male-dominated culture. Their works, which mostly explain male discourses, can't be regarded as female literature in its true sense.

Chinese contemporary female literature was born in the early $20^{\text {th }}$ century. The introductions of western thoughts and anti-feudal struggles have directly caused the female ideological 
emancipation. "Many female works expressed women's unique emotion, cultural experience, gender experience through female discourse power, and protest against male-dominated society". Chinese female literature emerged at the right moment with representative female writers as Ding Ling, Ling Shuhua, Lu Ying, etc. For example, Ding Ling described in the end of The Diary of Mrs. Shafei "survive silently and pass away silently" and "Her heart wasn't willing, so she was depressed". These have reflected young female's dissatisfaction and defiance against anguish of the age and traitorous harm. After the May 4th Movement, contemporary female writer groups in the history of Chinese literature were formed. They quickly took a certain position in the literary world, announcing that Chinese female would never keep silent in literature creation and wouldn't be auxiliary any more.

Chinese female literature formed independent writing way and writing style from the 1980s or the 1990s. After the reform and opening-up policy, with deep transformation of social culture, female ideology has been constantly set free. Chinese female writers finally got rid of traditional male chauvinism, realized "de-sexualized writing" in its true sense, and created plenty of literary works with bright female consciousness and emotional characteristics. Especially in the $21^{\text {st }}$ century, various schools of western feminism thoughts and their literature works gradually flowed into China, mixed together with female writers' creative ideas, vigorously promoted the diversification and prosperity of Chinese contemporary female literature, and stimulated the prosperous development of female literature. During this period, female writers have created so many literary works with characteristics of times and female. The most representative works are Love is Unforgettable written by Zhang Jie, The Scream of the Butterfly written by Wei Hui, Every Good Kid has Candies written by Mian Mian, The Sexual Consciousness of an Age and Story of Bai Juan in a Small Town written by Wei Wei, etc. The most influencing work is Shu Ting's To the Oak Tree. She described in the poem that "I must be a Bombax ceiba beside, and stand by you as the image of a tree”, expressing female's self-ideas of independence, self-esteem, self-confidence, and self-improvement, and strong self-awareness. It is the typical representation of contemporary female discourse system.

\section{Impacts of cultural transformation on female culture}

Culture is the core and soul of society. The significant embodiment of social progress is whether the culture has been developed. Cultural transformation means replacing the old culture with new one. It is embodied in culture revolution and progress with its essence as the transformation process of dominating cultural patterns in specific times, specific nation and specific social group. At the same time, cultural development transformation will also react on any thing in society including female literature. Chinese culture has a long history with unique cultural charm and many deficiencies and handicaps. In particular, emphasizing male chauvinism and neglecting female right have resulted in the fact that Chinese female literature as always the dependency of male literary has no independent position. The reform and opening-up policy brought great social development, ideological emancipation and culture prosperity. As a result, female literature was quickly awakened and developed, taking a significant position in the whole literary world. Plenty of literary works suitable for female physical and psychological characteristics have been created. However, traditional feudal culture, western female culture and the new culture generated by Chinese social structure characteristics were mixed with each other. Factors like female identity, social status, family role, etc have great impacts on the development of female culture.

\section{Influences of female identity}

With the progress and development of society, identity of Chinese contemporary female is gradually improved, winning recognition from people of all walks of life. However, there are two objective aspects of harmful trends. Firstly, some women "see only women no men", place too much emphasis on female identity, neglect their social identity, give up cultural transformation progress's requirement on female development when defend tenaciously the female identity, and mislead female literature to "female extremalization". Secondly, some women "see only men no women", recognize themselves as "social men", ignore their inherent "women" identity, and lack 
sexual ego and female awareness in society. As for them, such kind of deficiency may be caused by unawareness or deliberate absence. The action of vanishing female identity brings about the confusion of female roles and can't manifest the particularity of female literature. The harmful trends both have negative influences on female self- emancipation and female literature development.

\section{Influences of female social status}

Gender equality is an important criterion of social culture development, and female social status gradually wins recognition of society. Objectively gender differences always exist. There are also two harmful trends in process of understanding the essence of this problem. Firstly, some people overemphasize gender differences and give up the pursuit of equality. A few women think that gender differences are the source of gender inequality, there are intrinsic and irreparable differences between male and female thoughts and behaviors, and women possess an extremely inferior position. As a result, some people gradually belittle the female and even some female writers take male as standard. They consciously or unconsciously keep up with and get close to male traits of character. If the female literature is lack of personalized features of female application, it can't be called as female literature. Secondly, some people narrowly place gender equality and gender difference at two opposite places, holding that men and women should be the same except for some physical differences, so that it is the gender equality in its true sense. We should correctly and objectively treat all these. As what Mao Zedong has pointed out, "Even though China has carried out labor collectivization, gender equality legislation, social child-care, etc, it is still too early to say that Chinese have truly, radically and thoroughly changed their attitude towards women". [3] Therefore, we should realize that the gender equality emphasized currently is objective equality of culture, right, and spirit. In specific problems, it still varies with each individual and different gender, fully presenting the physical, psychological and characteristic differences brought by gender. It is the same for female literature creation.

\section{Influences of family and social relationship}

Women's stepping into the public domain dominated by male is significant embodiment of social progress, but we shouldn't ignore the influences of family on female. Ding Ling has experienced the contradiction between women liberation and traditional family structure in writing Thoughts on the Women's Day. In addition, "although women live in a revolutionary regime of changing society, the regime doesn't change traditional family structure which is used to repress the female”. [4] Family as a cell of society is a basic unit people need to survive. At the same time, influenced by physiological and physical conditions, family members also have different division of labor. It represents complementary feature of family. In general, the husbands pay attention to external activities like job, education, communication, etc, maintain favorable relationship between family and society, undertake the heavy muscular labor in family; while the wives are mainly in charge of internal affairs in family like raising babies, supporting parents, washing, cooking, and maintaining favorable internal relationship among family members. "The role of husbands is fixed on external affairs of a family. They make money, support family and establish their families' position in society. The role of wives is fixed on internal family affairs. They are wives, mothers, and also the managers of family". [5] With the constant development of female liberation activities, the amount of professional woman increases year after year. More and more women are trapped in the contradiction of selecting family and jobs, facing conflicts that they can't have the two together. A woman, who achieves success no matter in family or job, should sacrifice one for the other. This is also the reason why many women don't want to be called as "able woman" or "iron lady". The influences determine the female literary thoughts and literary appreciation orientation and also affect the creation and development of female literature.

\section{Developing and changing tendency of Chinese contemporary female literature}

Chinese contemporary female literature emerges with the embryo of Chinese contemporary literature, following closely the pace of reform and development, and cultural transformation in 
China. It is the most vigorous and potential component of Chinese contemporary literature. It can be said that Chinese contemporary literature is facing the maturity of adapting to female. The open and growing maturity stimulates Chinese contemporary female literature to develop and change in a more diversified orientation with more characteristics of times.

\section{Highlighting self-awareness more}

The constant liberation and independence of female thoughts and awareness further strengthened female self-awareness. Consequently, women's expression in aspects of life self-experience, female ontological representation, female value realization, etc will become more inherent, obvious and generous. In aspect of literature, female writers put this kind of awareness on the stage, conduct processing with artistic means, promote female self-consciousness of female literature, and form literature creation modes with female individual characteristics. Such kind of literature creation mode generally abandons political points and significant theme. It uses personalized and private writing to establish position of female literature, cuts into society from the main roles in daily life like sentimentality, housework, life experience, children education, etc, and creates literature.

\section{Fitting physical and mental characteristics more}

Women's physiological characteristics determine that female psychology is different from male psychology in certain aspects. The awakening and development of female literature turn "use body to write" female literature into scenery of female literature developing and changing. To a certain extent, "use body to write" has moved towards an extreme of female literature, but it indeed creates new space and domain for female literature development and provides female writers with unprecedented literary creating ways unique for new generation. It makes female literature more suitable for women's physical and mental characteristics and stimulates the development and perfection of female literature. For example, describing the popular literature like termagancy and grimness of male-dominated society in daily life manifests the female's confusion in reality.

\section{Emphasizing gender consciousness more}

Female's gender is inherent. Literature comes from society and is higher than society. Only by focusing on female intrinsic gender characteristics can female literature have vitality and infectivity. For example, Personal Life created by Chen Ran and The Rose Door written by Tie Ning mainly describe women's inner spiritual world and emphasize women's gender consciousness in creation. Such kind of literary creation takes women's gender consciousness as basis and core. As a result, female literature achieves unprecedented progress in literary circle, and literature also takes a key step in a more diversified, abundant and prosperous orientation.

\section{Acknowledgments}

This paper is a school-level project named Research on Chinese Contemporary Female Literature and Ecological Feminism Criticism. Project number: XTXY13YB025

\section{References}

[1] Tan Zhengbi. The History of Chinese Female Literature [M ]. Tianjing: Baihua Literature and Art Publishing House, 2001:278.

[2]Zhao Shuqin. Desire and anxiety of contemporary female discourse power [J]. Social Sciences Journal of Hunan Normal University, 2001(3)

[3] Alan Swingerwood. Translated by Feng Jiansan. The Myth of Mass Culture, Beijing: SDX Joint Publishing Company, 2003

[4] David Der-wei Wang. Translated by Song Weijie. Repressed modernity--- new theory of late-Qing fictions, Beijing: Peking University Press, 2005

[5] K. Marx \& F. Engels. Selections of K. Marx and F. Engels (Vol. 4), [M], People's Publishing House, 1973, p 91 